\title{
Reverse Party Favoritism in Times of Pandemics: Evidence from Poland
}

\author{
Jarosław Kantorowicz ${ }^{1}$ \\ Leiden University
}

\begin{abstract}
There is an abundant empirical literature demonstrating party favoritism whereby the central government is prone to disburse financial transfers to favor aligned local governments. This contrasts with much scarcer evidence on reverse party favoritism, i.e. aligned local governments offering non-pecuniary support to the central government in times of elections. In this paper I show that such reverse party favoritism exists. To demonstrate it, I exploit the fact that during the SARS-CoV-2 pandemic crisis, the Polish government was keen to launch postal voting in the presidential elections scheduled for May 2020. The organization of these elections hinged on the Polish Post getting access to the lists of voters, which were in the possession of heads of the municipal executive (mayors). Since the relevant legislation on postal voting had not been enacted on time, the vast majority of local executives refused to share their lists of voters. Nonetheless, numerous mayors did transfer the lists to the Post. By employing a set of standard (linear probability and logistic) regression models and regression discontinuity design, I show that the political alignment of mayors with the central government leads to approximately 20-25 percentage points greater likelihood of transferring the lists of voters to the Polish Post. This difference in probabilities tends to be smaller in cases of divided governments but not in cases of higher political contestability.
\end{abstract}

Keywords: party favoritism, fiscal federalism, pandemics, regression discontinuity design

\footnotetext{
${ }^{1}$ Institute of Security and Global Affairs and Department of Economics, Leiden University, Turfmarkt 99, 2511 DP, Den Haag; E-mail address: j.j.kantorowicz@fgga.leidenuniv.nl.

I would like to thank Ms. Martyna Bójko from the Citizens Network Watchdog Poland who kindly shared with me the data on the outcome variable used in this paper.
} 


\section{Introduction}

The second generation of fiscal federalism literature is quite consistent in arguing that transfers from higher to lower levels of government do not merely follow the economic efficiency criteria such as exploiting economies of scale or containing externalities (Oates, 2005). In line with this literature, the considerations of political economy do matter insofar as transfers from higher (central) governments are used to maximize votes and the re-election prospects of political agents deciding on intergovernmental grants. The two main models in this vein are the "core voters" and "swing voters" models (for more on the taxonomy of these two models, see Cox, 2010). While the former model assumes that (risk averse) central governments use intergovernmental grants to target their core supporters in order to mobilize them to vote (Cox \& McCubbins, 1986; Kauder et al., 2016), the "swing voters" model says that the allocation of grants is proportional to the number of undecided voters (Lindbeck \& Weibull, 1987; Arulampalam et al., 2009). Recent studies further assume that because of the "leakage" of benefits from the intergovernmental transfers to local governments ${ }^{2}$, another aspect enters the strategic calculus at the central level. Namely, central governments may allocate the transfers to local governments in such a way as to maximize the electoral chances of aligned governments or to hamper the chances of unaligned ones (Larcinese et al., 2006; Solé-Ollé \& Sorribas-Navarro, 2008). The expectation is, as the argument goes, that the aligned local governments may be important opinion leaders and may prove to be essential supporters of parties at the central level in the next national elections (Brollo \& Nannicini, 2012; Migueis, 2013; Bracco et al., 2015; Curto-Grau et al., 2018; Lara E. \& Toro M., 2019). Thus, targeting aligned localities with intergovernmental transfers pays off from the point of view of the central government as they may count on local governments' support in the subsequent central level

\footnotetext{
${ }^{2}$ Local populations may reward local governments for an increase in spending or investment instead of the central government as people are not fully aware how local income is generated.
} 
elections. This last aspect is precisely what this paper is interested in. While an abundant literature exists showing that central governments disburse the grants to aligned local governments (party favoritism), there is not much direct evidence that aligned governments reciprocate this favor in other non-pecuniary ways such as, for instance, by supporting the central government in the national elections. This paper fills this gap. For the purpose of this paper, I call this latter phenomenon reverse party favoritism.

The Polish case presents itself as an ideal setting for testing whether reverse party favoritism exists. The outbreak of the SARS-CoV-2 pandemic crisis in March 2020 put into question the organization of the presidential elections ${ }^{3}$ scheduled for May 10, 2020. Despite popular disapproval ${ }^{4}$, the ruling party (Law and Justice; PiS ${ }^{5}$ ) was nonetheless pursuing the idea of elections taking place on May 10. This was largely driven by the fact that the PiS nominee - the incumbent president Andrzej Duda - had at that time a significant lead over other presidential candidates in electoral polls ${ }^{6}$. The PiS had

\footnotetext{
${ }^{3}$ Constitutionally speaking, Poland follows the semi-presidential governance structure, whereby the executive is embedded within the government and the President of the Republic of Poland. While the government, led by Prime Minister, is formed by the political parties, which constitute the majority in the lower chamber of the parliament (Sejm), the President is popularly elected from the candidates (typically) nominated by the political parties. Although, undoubtedly, the Prime Minister has a stronger position within the executive, by no means the role played by the President is minor. Most importantly, the President can veto bills of the parliament or refer them to the Constitutional Tribunal for abstract (preventive) constitutional review. As a result, the President constitutes a key element in the system of checks and balances.

${ }^{4}$ At the beginning of May 2020, around 59\% of the respondents were intending to abstain from postal voting if the elections were to be organized on May 10, 2020. Source: United Surveys poll commissioned by Dziennik Gazeta Prawna and RMF FM https://www.rmf24.pl/raporty/raport-wybory-prezydenckie2020/sondaze/news-sondaz-dla-rmf-fm-i-dgp-polacy-nie-chca-wyborow-10-majapraw,nId,4480479 (last accessed December 6, 2020).

${ }^{5}$ The Law and Justice (PiS) is the main party of the conservative political alliance United Right. The United Poland (Solidarna Polska) and the Agreement (Porozumienie) are two junior partners in this alliance. The major opposition parties are the Civic Platform (Platforma Obywatelska) and Democratic Left Alliance (Sojusz Lewicy Demokratycznej), which are members of two different coalitions, the Civic Coalition and the Left, respectively. The Polish People's Party (Polskie Stronnictwo Ludowe) is another opposition party, which has a relatively good presence in the local governments.

${ }^{6}$ For instance, on May 1 the support for A. Duda reached $63 \%$ guaranteeing victory in the first round of presidential elections. Source: IPSOS survey commissioned by the OKO.press portal
} 
preferences for launching a system of postal voting, thus departing from traditional voting in person at a polling station. To this end, PiS started with the legal provisions taking away the right to organize the elections from the National Electoral Commission $^{7}$. The plan was to task the Ministry of Interior Affairs and, specifically, the Polish Post with sending ballot papers to all eligible voters. The problem, however, was with gaining access to the lists of eligible voters, which in Poland are maintained by mayors, i.e. the popularly elected heads of government in the municipalities (the lowest tier of devolved government). As the relevant law on postal voting had not been enacted before May 10, many interpreted the requests for access to the lists of voters sent to mayors by the Polish Post as having no legal force. Numerous non-governmental organizations advised the municipalities not to share the lists, arguing that requests from the Polish Post were illegal and the local authorities (mayors) should thus ignore them. On the other hand, the state agents such as governors of voivodships ${ }^{8}$ (appointed by the prime minister) urged the mayors to comply with the request by referring to art. 99 from the special law on instruments to contain the spread of the SARS-CoV-2 virus. $^{9}$ Some mayors followed the governors' appeal and shared the lists of voters, arguably breaking the law ${ }^{10}$. The question thus arises of which mayors are more likely to support the central government in the electoral effort.

https://oko.press/sondaz-holownia-wygral-kampanie-duda-wygra-glosowanie/ (last accessed December 6, 2020).

${ }^{7}$ Pursuant to Art. 102 para. 6 of the special law on instruments to contain the spread of the SARS$\mathrm{CoV}-2$ virus the Polish Election Commission was stripped of the responsibility for designing and printing the ballot papers.

${ }^{8}$ A government layer situated between the center and the municipalities.

${ }^{9}$ Art. 99 of the special law on instruments to contain the spread of the SARS-CoV-2 virus obliges public authorities to pass the lists of voters upon the request from the Polish Post, if this information is necessary for the performance of tasks related to the organization of the election of the President of the Republic of Poland or for the performance of other obligations imposed by government administrative bodies. The problem lay, however, with the fact that the statute formalizing the postal elections had not been passed before May 10, 2020.

${ }^{10}$ The municipalities might have been in breach of art. 51 para 5 of the 1997 Constitution of Poland, which stipulates that principles and procedures for the collection of and access to information shall be 
I find that the probability of sharing the lists of voters is roughly 20 percentage points higher in the municipalities with politically aligned mayors than in the municipalities with unaligned mayors. This difference increases to 25 points if one compares the aligned and misaligned mayors (mayors affiliated to the opposition parties). These estimates are obtained by both standard regression (linear probability) models as well as regression discontinuity (RD) design models based on the margin of victory between aligned and non-aligned mayoral candidates. In the case of the latter model, the results appear to be not statistically significant due to the lack of statistical power. There is also further (weak) evidence that the relationship between the political alignment and the probability of sharing the lists of voters is moderated by the situation of divided government. More precisely, the aligned mayors whose party does not have a majority in the local councils are by 10 points less likely to share the lists than aligned mayors whose parties have this majority. Lastly, there exists large and strong association between the likelihood of sharing the lists and local popular support for the PiS (ideological alignment). Greater support for the PiS in the parliamentary elections of 10 points translates into a 7-8 points larger probability of sharing the lists of voters.

This paper is structured as follows. In section 2, I briefly sketch the theoretical expectations tested in this paper. Section 3 discusses the data sources and methods applied to test the hypotheses and section 4 presents the results. Finally, section 5 concludes the paper.

\section{Theoretical expectations}

I offer several theoretical expectations for when (the mayors of) local governments are more or less likely to support a central government in an electoral effort. First and

specified by statue. And also, in relation to art. 7 of the Constitution, which says that the organs of public authority shall function on the basis of, and within the limits of, the law. 
foremost, from the point of view of this paper, the mayors are more likely to support the central government when they are politically aligned with the center. Political alignment is defined as a situation where a mayor is affiliated to the ruling party or one of the ruling parties in the case of coalition governments or if the mayor is officially endorsed by one of the governing parties. There are two possible explanations for what may lead the aligned mayors to support the central government. First, aligned mayors may want to return favors for their treatment by the central government which tends to allocate higher transfers to aligned localities (Brollo \& Nannicini, 2012; Migueis, 2013; Bracco et al., 2015; Curto-Grau et al., 2018; Lara \& Toro, 2019). In the Polish context this explanation seems to be plausible. For instance, Kantorowicz (2017) and Kantorowicz \& Köppl-Turyna (2019) show that transfers from the central government sharply increase in the municipalities with the population size above 20,000 inhabitants. These municipalities are governed by proportional electoral system and observe much greater shares of candidates from national political parties as compared to smaller municipalities where either block or majoritarian voting prevails promoting mostly local political committees. Also, Banaszewska \& Bischoff (2017) demonstrate that political alignment is an important determinant of disbursement of the EU funds from the higher level governments to the municipalities. Likewise, in a recent study Swianiewicz (2020) shows that municipalities ruled by the PiS mayors enjoy disproportionately high transfers from the Local Governments Roads Fund (Fundusz Dróg Samorządowych). The second possible explanation is that aligned mayors may want to support the central government as they expect to be promoted within the party structures in the future (Curto-Grau et al., 2018). As it is rather difficult to empirically test the latter channel, in this paper the finding of political alignment would assume the presence of these two channels of transmission.

The effect of the political alignment on electoral support for the central government might be moderated by at least two conditions and, in particular, in the situations 
when supporting the center arguably requires crossing legal boundaries. The first (moderating) condition is political contestability. In the political environments where the election of a mayor is highly contested or, in other words, competitive, the executive is held more accountable, since political rivals and the population at large are more likely to closely scrutinize decisions of mayors and put mayors into the negative spotlight for wrongdoings (Alesina \& La Ferrara, 2000; Fitzgerald \& Curtis, 2012; Jones, 2013). Hence, one should observe much greater support for the central government from the aligned governments which operate in an uncontested or uncompetitive political environment than those operating in highly contested localities. The second feature of the political system moderating the effect of political alignment might be the condition of divided government. In such a situation the party of an incumbent mayor does not have a majority in the local legislative body (municipal council) and thus the mayor-council relationship is arguably more adversarial. In the situation of a divided government, it is more difficult for the executive to force its own initiatives through a standard legislative process, resulting in an increase in the use of executive orders (see the strategic model by Deering \& Maltzman, 1999). However, similar to the condition of contestability, the decisions of the executive may be more diligently scrutinized by the legislative body in the case of divided government; these may apply to even those decisions which do not require any legislative process to be binding such as administrative decisions, including the passing of the lists of voters in the Polish context. Overall, it is expected that aligned mayors ruling in the situation of a divided government are less likely to support the central government in an electoral effort than aligned mayors ruling under a unified government.

The political alignment explanation can be differentiated from the ideological alignment. In other words, mayors are prone to support the central government even if they are not from the same party or are not officially endorsed by the center, but their political preferences are similar to those of the central government. Taking this 
argument even further, the mayors may be neither politically aligned nor ideologically aligned with the central government but the local population they represent may be largely supportive of the central government and in this case the mayors may also be more likely to support the center. As it is quite difficult, if not impossible, to gather data on individual ideological positions of mayors and assuming that mayors' ideological stance is a reflection of the ideological position of the local population, it seems sufficient to capture the ideological position of the population at the level of the municipality. Based on this it is expected that mayors are more likely to support the central government when the population they represent is ideologically aligned with the central government. This last argument resembles the "core voters" model with the caveat that this model was conceptualized in the context whereby the central government supports its core local constituencies, while here the core local constituencies are argued to be more inclined to support the center.

Given that municipalities at large heavy rely on intergovernmental grants for their budgetary revenues ${ }^{11}$, the central government could therefore use a stick of shifting some transfers away from the non-supportive municipalities or a carrot of allocating new grants to the supportive municipalities ${ }^{12}$. Particularly receptive to this threat should be municipalities observing high transfer dependency scores, thus the municipalities having a lower capacity to generate their own income ${ }^{13}$. In this municipalities the reduction of intergovernmental transfers can't be easily compensated by raising revenues locally. It might be different in the municipalities where a local tax base is

\footnotetext{
${ }^{11}$ On average, $62 \%$ of municipal revenues come from intergovernmental transfers and the remaining $38 \%$ are own municipal revenue (own calculations based on the information from the Bank of Local Data).

${ }^{12}$ There were general concerns among the local governors that the central government might be using political calculus in disbursing grants from a newly created Governmental Fund for Local Investments (Rządowy Fundusz Inwestycji Lokalnych). Source: https://katowice.wyborcza.pl/katowice/7,35063, 26160324,fundusz-premiera-morawieckiego-moze-podzielic-samorzady-na-pisowskie.html (last accessed December 6, 2020).

${ }^{13}$ The municipalities observing a high transfer dependency ratio can be described as less wealthy.
} 
large and a potential decline in transfers could be balanced by imposing higher levies locally. All in all, it is expected that mayors from the more transfer dependent (poorer) municipalities should be more apt to cooperate with the central government than the mayors from less transfer dependent (wealthier) municipalities.

Lastly, one should also consider political realities of the multilayered governance whereby the intermediary levels of government may also be politically aligned with central government. Under these circumstances, mayors might be more inclined to comply with the central government requests if the regions (intermediary levels of government) are ruled by the same political parties as the ones governing at the central level. The reason behind it is that regions are also involved in the disbursement of intergovernmental transfers ${ }^{14}$ and decide on many strategic issues from the point of view of municipalities (e.g., the location and maintenance of roads, public transportation network, etc.). Overall, mayors should be more inclined to support the central government if the intermediary levels of government are dominated by the same political parties as the ones governing at the central level.

\section{Data and methods}

The data on the outcome variable, i.e. whether the municipalities shared the lists of voters or not are obtained through the non-governmental organization Citizens Network Watchdog Poland (CNWP). In late April 2020, the CNWP sent a request to all municipalities requesting access to public information whether mayors shared the lists of voters with the Polish Post or not. Four levels of the outcome variable were coded by the CNWP. These levels are: 1) lists of voters shared, 2) lists of voters shared but without the password to access them, 3) lists of voters not shared, and 4) no response.

\footnotetext{
${ }^{14}$ In Poland the voivodships (a layer below the center) are heavy involved in deciding on EU funds transferred to municipalities and the decision-making processes are to some extent discretional allowing political factors to play a role in the allocation of funds (Banaszewska \& Bischoff, 2017).
} 
This coding was thoroughly verified by my own independent review of all documents submitted by the municipalities to the CNWP by October $2020^{15}$. While the basic coding system was replicated, several adaptations of the assigned scores were necessary in light of the submitted documentation. For instance, the coding performed by the CNWP did not consider documents, which were submitted too late by the municipalities. Figure 1 presents a spatial distribution of the outcome variable (note that this figure groups levels 1 and 2 of the outcome variables into a single category) in all 2477 municipalities. The figure shows that the municipalities, which shared the lists of voters tend to be located in the eastern part of Poland, thus in the stronghold of the PiS. For the purpose of the empirical analysis, the outcome variable is transformed into three separate binary variables. The first one takes the value of 1 if the lists of voters were shared, thus irrespective of whether the passwords were shared or not; the value of 0 is assigned if the lists were not shared (municipalities which ignored the request are coded with missing values). To account for the fact that sharing the lists without the password was not giving access to voters' records $^{16}$, the second binary outcome variable is coded as 1 if the mayor shared the lists and 0 if they did not share or shared the lists without the password (in this case also, the municipalities ignoring the request are assigned a missing value). Lastly and explicitly capturing for the responsiveness of the mayors, the third binary outcome variable takes the value of 1 if the municipality

\footnotetext{
${ }^{15}$ All the documents of correspondence between the Citizens Network Watchdog Poland and municipalities are publicly available and can be found under the following URL: https://fedrowanie.siecobywatelska.pl.

${ }^{16}$ It is not entirely clear what the motives of mayors sharing the lists without the passwords were. Two plausible explanations are as follows. First, the mayors might have wanted to show a good will for cooperation with the central government by sending the lists but also acknowledging the legal problems related to this action. Second, this could have been nothing else than 'malicious compliance'. The municipalities might have wanted to officially comply with this request knowing that the information they provided is useless from the point of view of the Post. Given where the municipalities which sent the lists of voters with no passwords are located (mostly in the East and close to the municipalities which fully shared the lists of voters), the first explanation seems to be somewhat more plausible (see Figure A1 in the supplementary material).
} 
responded to the query sent by the CNWP to access public information and 0 otherwise.

Figure 1. Spatial distribution of the outcome variable

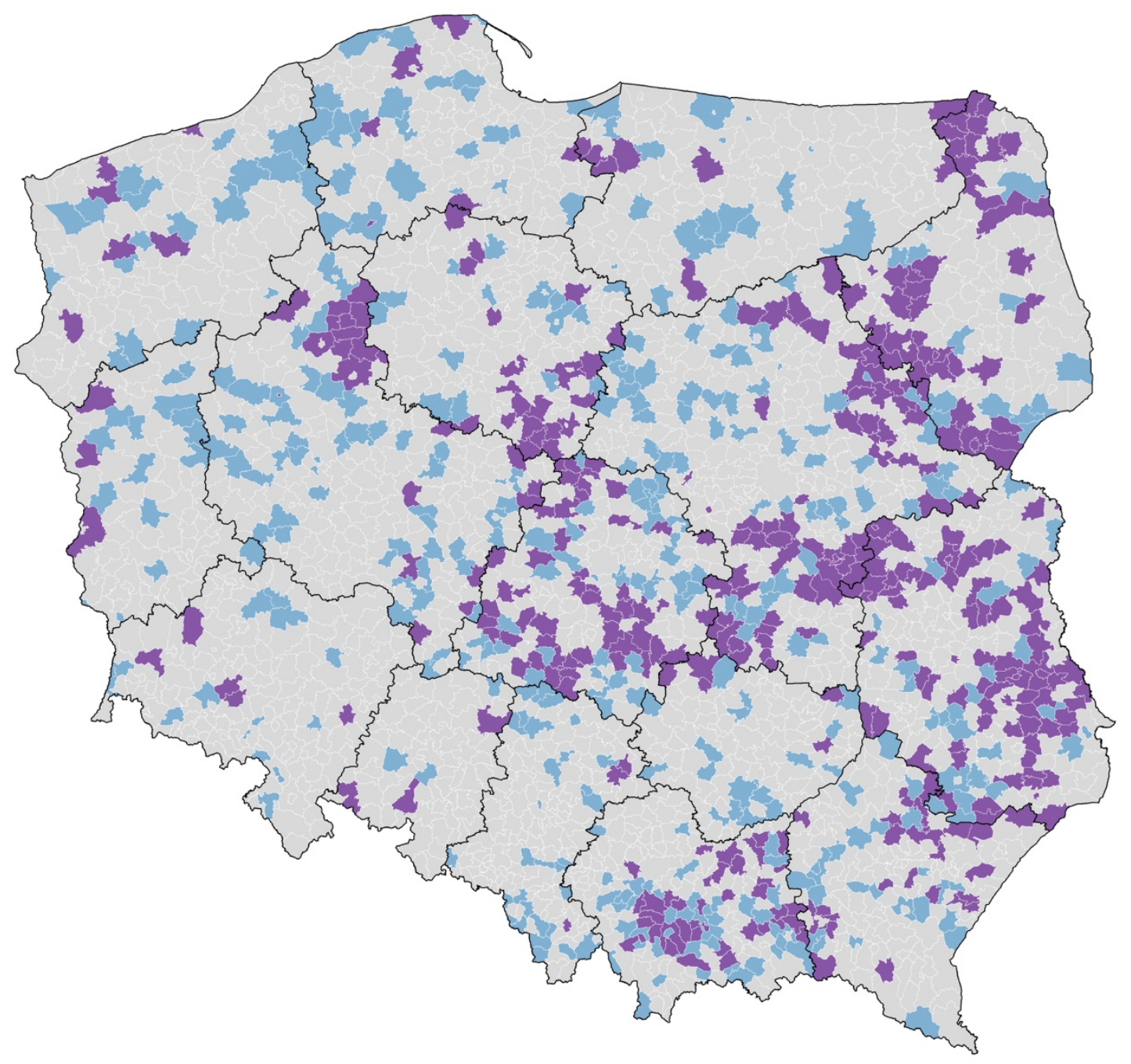

Lists of voters transferred to the Post: $\square$ Yes $\square$ No or vague response $\square$ No

The main explanatory variable, i.e. political alignment, is coded in two different ways. The first coding captures the political alignment variable through a binary variable which takes a value of 1 when a mayor is affiliated with the PiS or its junior partners from the United Right alliance (Solidarna Polska and Porozumienie) or when a mayor is officially endorsed by one of the parties from the United Right. The value of 0 is 
assigned to all other cases. The two-level operationalization of the political alignment variable yields 255 aligned mayors. It is of note however that the majority of mayors in Poland (roughly 75\%) remain unaffiliated to (or not officially endorsed by) any political and nationally representative $\operatorname{parties}^{17}$. To acknowledge this peculiarity, the alternative coding of the political alignment variable distinguishes between three categories: (1) alignment, non-alignment and misalignment. The category of political alignment is coded in the same fashion as above. The misalignment captures situations whereby the mayors are affiliated to the opposition parties to the United Right alliance ( $\mathrm{N}=361)$. Finally, the non-alignment covers situations where the mayors are affiliated with local committees not endorsed by any of the political parties from the center $(\mathrm{N}=1,861)$. The difference in marginal means between the aligned and misaligned mayors may in fact provide the results that are more generalizable to other setups where the same political parties are present at both the central and local government levels. Data on the mayoral affiliations and endorsements from the most recent (2018) local elections is retrieved from the datasets provided by the National Electoral Committee. This data source is also used to construct two moderating variables, i.e. mayoral contestability and divided government. The former is a continuous variable measuring the margin of victory (closeness of elections) between the winning candidate and the runner-up in the first round of mayoral elections in 2018. The divided government, on the other hand, is a binary variable which takes a value of 1 if the mayor's party does not have a majority in the municipal council and 0 otherwise. Likewise, the National Electoral Committee serves to provide data on the percentage of the PiS councilors in both voivodship and county councils, the two tiers of intermediary

\footnotetext{
${ }^{17}$ Poland is rather an exception among European countries in terms of non-partisan presence at the municipal level. In 2010, only some $29.5 \%$ of councilors declared party membership in Poland. In contrast, in Czech Republic this was 66\%, in Spain 94.1\% and in Sweden 99.6\% (Gendźwiłł \& Żółtak, 2014, p. 1124).
} 
government situated one and two levels below the center, respectively. Currently, there are 16 voivodships and 380 counties in Poland.

To capture the ideological position (alignment) of the population at the municipality level, I extract data on the 2019 parliamentary election outcomes from the National Election Committee. These data allow the calculation of the share of votes given to the PiS (all candidates from the United Right coalition were included in the PiS electoral lists) at the municipality level.

The wealth of municipalities in the Polish context is typically proxied by their ability to generate own revenue (mostly through local taxes and fixed shares on national taxes levied at municipalities' territories). The data on the level of own revenue in 2019 is obtained through the Bank of Local Data of the National Bureau of Statistics. To make this measure comparable across municipalities, the per capita level of own revenue is computed.

As control variables, I further include several mayor-level characteristics such as gender (female or male), age (in years) and education of mayors (higher education versus other levels). Descriptive statistics for all variables are presented in Table A1 in the supplementary material.

In baseline regressions I use linear probability (LP) models estimated with OLS as they offer quick interpretability of estimated coefficients (Gomila, 2020). Nonetheless, as robustness checks, logistic regression models are run as well. In all models I cluster the standard errors at the county (powiat) level to account for a potential lack of independence of observations within a county.

In an attempt to provide causally interpretable results, I further employ regression discontinuity $(\mathrm{RD})$ design to find the effect of political alignment on the likelihood of sharing the lists of voters. To this end, the analysis is limited to only those municipalities which in 2018 had one mayoral candidate affiliated to, or endorsed by, the United Right (in the vast majority of cases this was just the PiS). The location and 
characteristics of municipalities used in the RD design is presented in Figure A2 and Table A2 (supplementary material), respectively. In these cases, I am able to use a difference between the shares of votes obtained by the best non-United Right candidate (either winner or runner-up) and the United Right candidate as the running variable in the $\mathrm{RD}$ model. The negative values of the running variable capture the victories of the United Right candidates, whereas the positive values show that they lose the mayoral elections. Most importantly from the point of view of this empirical strategy is that the values near zero capture close contests where small difference in votes translate into large difference in terms of who governs the municipality. Of interest in the $\mathrm{RD}$ models is the estimate demonstrating the sharp change in the outcome variable at the threshold. The RD model employed in this paper performs local polynomial regressions and uses conventional and robust bias-corrected estimators with optimal bandwidth selection procedures in line with Calonico et al. (2020).

\section{Results}

\subsection{Standard regression models}

Looking first at the bivariate relationships between the outcome variables and the main explanatory variable, i.e. political alignment (see Table A3 in the supplementary material), there are quite sizable and statistically significant differences in the likelihood of sharing the lists of voters between aligned and unaligned mayors (based on the two-level operationalization of the political alignment variable). This holds for both types of outcome variable, i.e. for the variable that interprets the sharing of lists with no password as simply an act of sharing (t-test: diff $=0.28,|\mathrm{t}|=10.20$; Chi-square test: $\left.\chi^{2}(1)=99.2\right)$ and for the variable that assumes that sharing the lists without the password should not be interpreted as an act of sharing (t-test: diff $=0.26,|t|=10.0$; Chi-

square test: $\left.\chi^{2}(1)=95.6\right)$. No relationship exists however between the responsiveness 
of mayors and their political alignment (t-test: $\operatorname{diff}=0.01,|\mathrm{t}|=0.40$; Chi-square test: $\left.\chi^{2}(1)=0.1\right)$. What is noticeable from the bivariate comparisons is that not surprisingly the ideological alignment (support for the PiS) is higher in the municipalities with aligned mayors than in municipalities with unaligned mayors (t-test: $\operatorname{diff}=0.12$, $|\mathrm{t}|=13.65)$. Clearly, the support for the $\mathrm{PiS}$ is a confounding variable that reinforces the necessity to control for this variable in the multiple regression models.

Moving beyond bivariate relationships, Figure 2 displays the estimated coefficients from the multiple LP models where the outcome variables are regressed on a full set of explanatory and control variables without the interaction terms for testing the moderation effects. As seen from this figure, there is a positive relationship between the political alignment (based on the two-level operationalization of the political alignment variable) and the likelihood of sharing the lists of voters (coded either way) of roughly 20 percentage points. The ideological alignment variable is also positively associated with the probability of sharing the lists of voters. A 10 points greater support of the PiS translates into a 7-8 percentage points higher probability of sharing the lists. All these results are statistically significant at $1 \%$ level. Other explanatory variables are not statistically significant at the conventional $5 \%$ level. These results are robust for applying logistic regressions. The full models are presented in columns 1 (LP model) and 4 (logit model) of Table A4 and A5, respectively (see the supplementary material). One should further notice that none of the main explanatory variables correlates with the responsiveness of mayors. 
Figure 2. Estimates for the main variables from the LP model

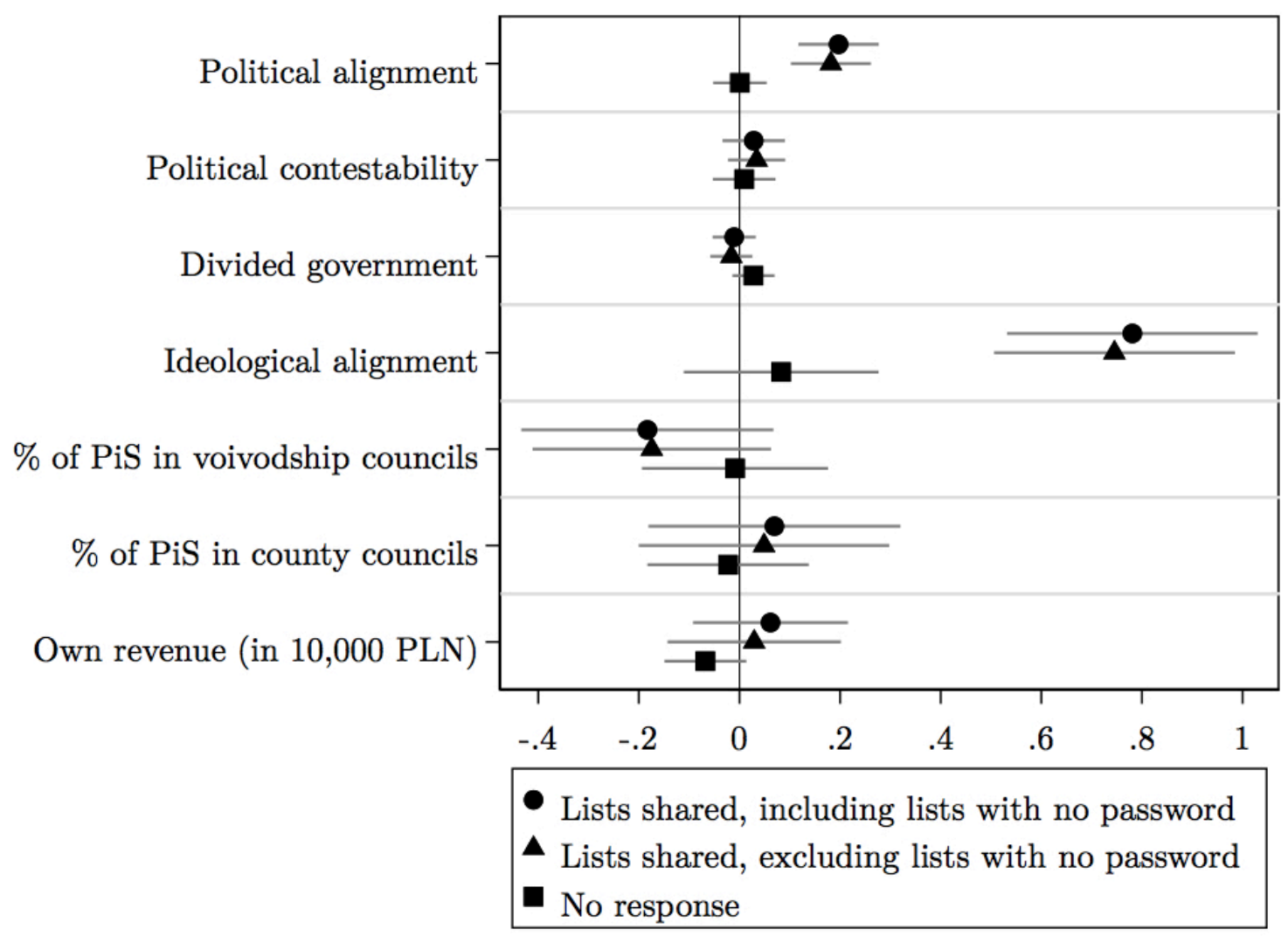

Note: This figure displays the estimated coefficients from the LM model with standard errors clustered at the county (powiat) level. Besides the variables included in the figure, the model further controls for age, sex, education.

Since the analysis thus far rely on the two-level operationalization of the political alignment variable, which compares aligned and unaligned mayors, in the next step I perform the same set of OLS regressions with the three-level alignment variable. With this, one is able to distinguish between the misaligned mayors (mayors affiliated with the opposition parties to the United Right alliance) and non-aligned mayors (mayors affiliated to local committees). Figure 3 reports the results for this alternative coding of the political alignment variable. The estimates suggest that aligned mayors observe roughly 25 percentage points higher probability of sharing the lists of voters than misaligned mayors. Furthermore, the probability for non-aligned mayors to share the lists is greater by some 5 percentage points than for misaligned mayors. One may argue 
that this alternative coding provides results which are more generalizable to local contexts in other countries where the political parties from the central level also compete at the local level. The full models are presented in columns 1 (LP model) and 4 (logit model) of Table A7 and A8, respectively (see the supplementary material).

Figure 3. Estimates for the alternative coding of the main explanatory variable from the LP model

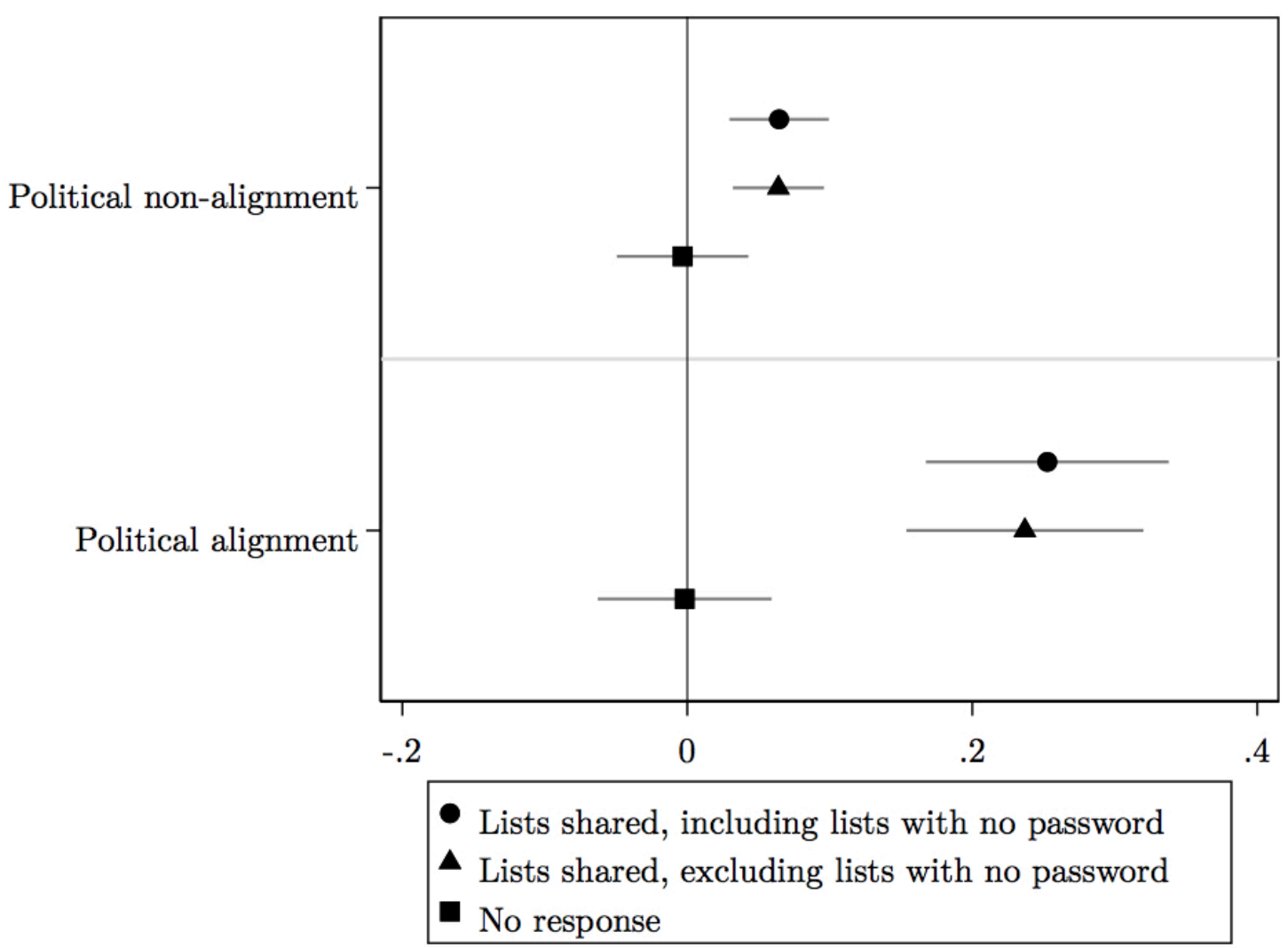

Note: This figure displays the estimated coefficients from the LM model with standard errors clustered at the county (powiat) level. Besides the variables included in the figure, the model further controls for political contestability, divided government, ideological alignment, $\%$ of PiS in voivodship council, $\%$ of PiS in county council, own revenue, age, gender and education.

Moving to the interaction models, Figure 4 shows the marginal effects of the political alignment variable in the outcome variable at various levels of moderating variables, political contestability and divided government, respectively. As shown in Panel A of 
this figure, the relationship between the political alignment and the probability of sharing the lists (including the lists with no passwords) does not depend on the level of political contestability as it always oscillates around 20 points. In line with the procedure suggested by Hainmueller et al. (2019), it was further verified if a non-linear interaction model (binning model) is more appropriate for testing a conditional hypothesis. The Wald test cannot reject however the hypothesis that the linear and the binning models are equivalent $(\mathrm{p}$-value $=0.40)$.

This contrasts with the results displayed in Panel B of Figure 4 where the relationship between the political variable and outcome variable seems to depend on the level of moderating variable. The mayors in the situation of divided government are less likely to share the lists by some 10 percentage points. Nevertheless, this result is not statistically significant at the $5 \%$ level. This is arguably because of the relatively small number of observations in the category of politically aligned and divided government (55 observations), resulting in wide confidence intervals. Thus, one should conclude that there is only tentative evidence for the moderating effect of the divided government variable. Columns 2-3 (LP models) and 5-6 (logit models) in Tables A4 and A5 in the supplementary material show the corresponding regression tables, which test the moderating effects. Table A6 (supplementary material) shows the relevant estimation results for the responsiveness outcome variable. As seen there, none of the variables serves as a good predictor of this variable. 
Figure 4. Estimates of the interaction effects from the LP model
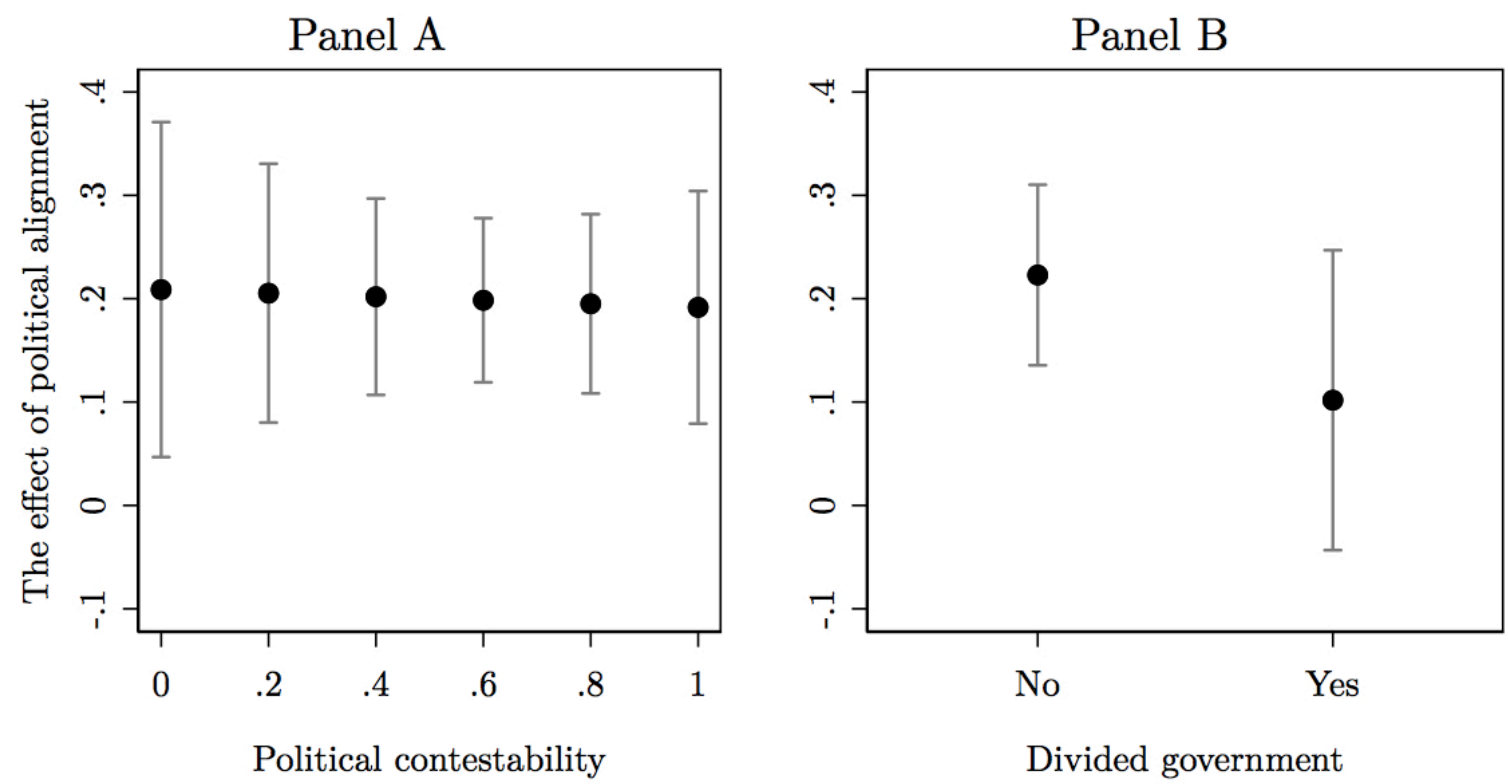

Note: This figure displays the marginal effects from the LM model with standard errors at the county (powiat) level. The outcome variable is a dummy denoting that the lists of voters were shared, including the lists with no passwords. Besides the variables included in the figure, the model further controls for ideological alignment, \% of PiS in voivodship councils, \% of PiS in county councils, own revenue, age, gender and education.

\subsection{Regression discontinuity design}

The previous section provides evidence that there is a positive relationship between the political alignment (based on the two-level operationalization of the political alignment variable) and the probability of sharing the lists of voters. In fact, the aligned mayors are some $20-25$ percentage points more likely to share the lists than unaligned or misaligned mayors. To give this result a causally interpretable flavor, I now turn to discussing the results from the RD design.

Figure 5 gives the first visual impression of the existence of a sharp discontinuity close to zero margin of victory. What is generally observed in this figure is a rather abrupt jump in the probability of sharing the lists at the threshold. For the mayors with a 
small negative margin of victory (PiS mayors) we observe, on average, roughly a $40 \%$ probability of sharing the lists (including the lists with no passwords). This contrasts with the mayors located just to the right of the threshold who show a $20 \%$ likelihood of sharing the lists. All in all, although the comparison is now performed on a subset of very specific municipalities (where there was one mayoral candidate from the United Right), the difference again amounts to some 20 points between the aligned and unaligned mayors. These differences become even larger if one considers mayors located further away from the threshold, but in these cases the causal interpretation is of course much less certain.

While the visual inspection of the discontinuity is a standard first step in the RD design, the more formal tests need to follow. Figure 6 thus displays the estimated coefficients from the RD models with different specifications (choice of the polynomials and bandwidths). What can be observed from Panel A and B of this figure is that the estimated coefficients fall around 20 points, yet apart from the first estimate computed with conventional method and with manually selected bandwidth of 50 , the results are not statistically significant at the $5 \%$ level. To be specific, this considers models applying bias-corrected and robust estimators as well as the polynomial of degree 2 . 
Figure 5. Visual inspection of discontinuity

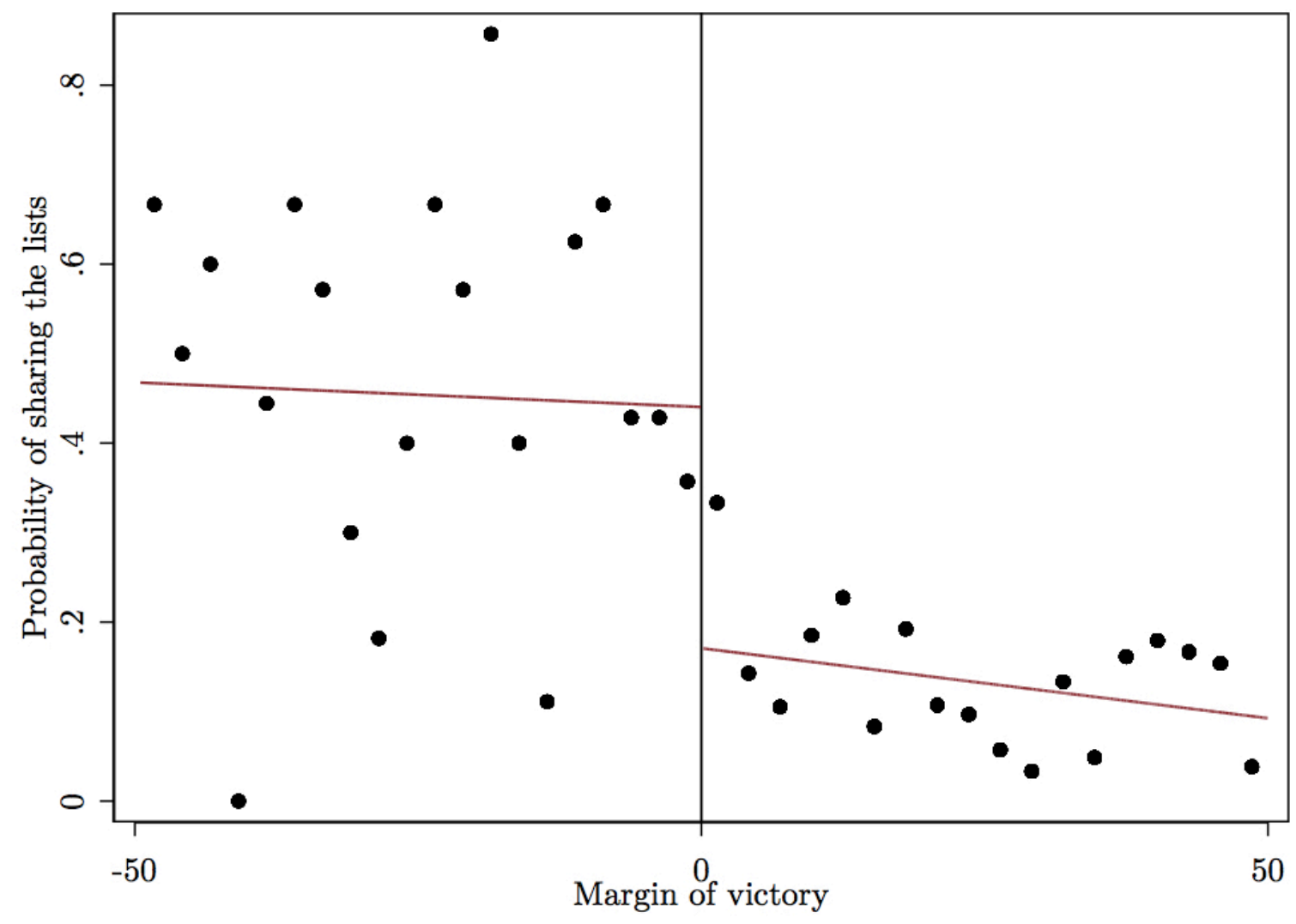

Figure 6. RD estimates for all three types of outcome variable
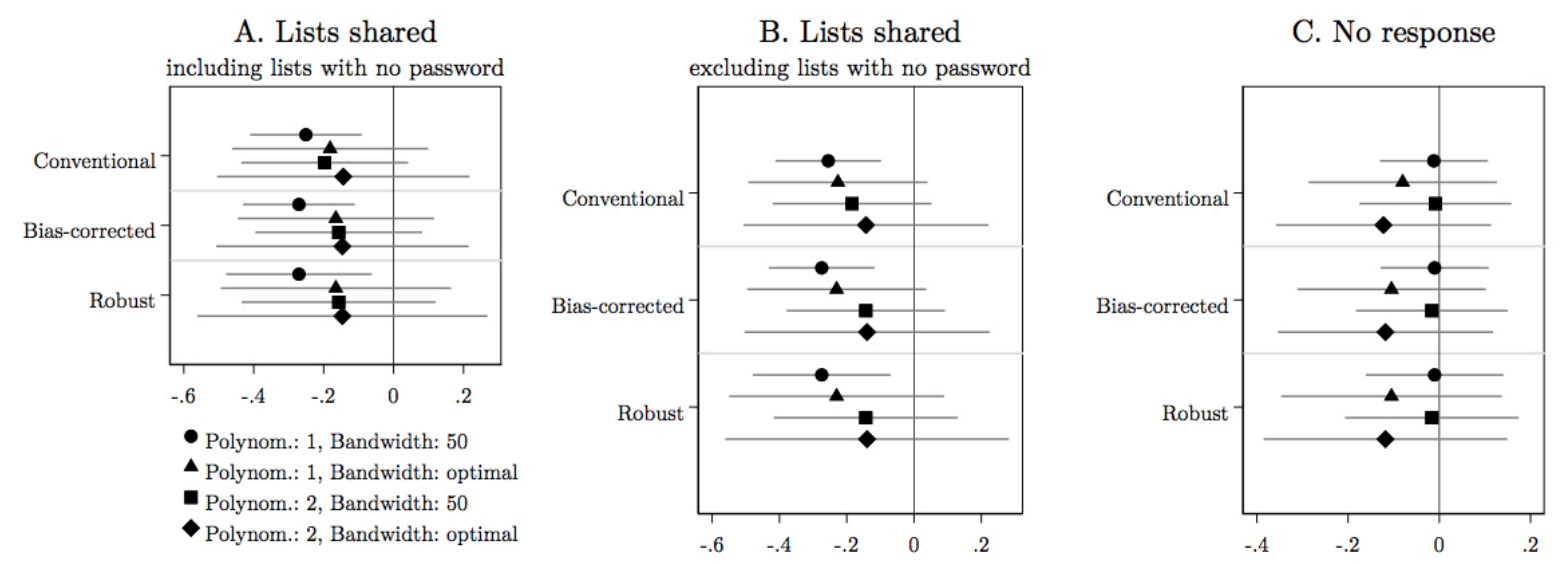

Note: All RD models presented in this figure control for political contestation, divided government, ideological alignment, \% of PiS in voivodship council, \% of PiS in county council, own revenue, age, sex and higher education. The uniform kernel is applied. 
Thus, even though the effects are quite large (20 points), they proved not to be statistically significant. This might be the result of a small sample size around the threshold. Given this, in the subsequent step, I test what statistical power this test achieves by applying ex-post power calculations for $\mathrm{RD}$ designs as specified by Cattaneo et al. (2019). The ex-post power of the test assuming the detected effect to be of some 20 percentage points ( $\tau=0.20$; as obtained in section 4.1 ) is only slightly above $20 \%$ (much less than the typically required $80 \%$ ). Figure A3 in the supplementary material shows that the power of $80 \%$ is achieved for only large effects of 50 points. To summarize, while substantively the local average treatment effect of 20 points is large and corresponds well with the estimates obtained through standard regression analysis, the lack of statistical power prevents the performance of conclusive hypothesis testing.

\section{Conclusions}

While there is an abundant literature demonstrating the evidence of party favoritism with which a central government tends to disburse the intergovernmental transfers to favor aligned local governments, much less empirical evidence is amassed on the reverse party favoritism, i.e. whether the aligned local governments offer non-pecuniary support to the central government in times of elections. In this paper I show that such reverse party favoritism is present. To demonstrate it, I exploit the fact that during the SARS-CoV-2 pandemic crisis, the Polish government was pushing for the launch of postal voting in the presidential elections scheduled for May 2020. The organization of these elections hinged on the Polish Post getting access to the lists of voters, which were in the possession of mayors. Since the relevant legislation enabling the mayors to transfer the lists of voters was not passed on time, the vast majority of local executives denied this request. Nonetheless, numerous mayors did pass the lists to the Post. I empirically show that the political alignment of mayors leads to a $20-25$ percentage 
points greater probability of transferring the lists of voters, depending on the operationalization of the political alignment variable. This difference in probability is smaller in cases of divided governments. The ideological alignment of the local electorate also explains the likelihood of sharing the lists with some 10 points increase in voting for the PiS translating into a 7-8 points greater probability in transferring the lists of voters. 


\section{References}

Alesina, A., \& La Ferrara, E. (2000). Participation in Heterogeneous Communities. The Quarterly Journal of Economics, 115(3), 847-904. https://doi.org/10.1162/003355300554935

Arulampalam, W., Dasgupta, S., Dhillon, A., \& Dutta, B. (2009). Electoral goals and center-state transfers: A theoretical model and empirical evidence from India. Journal of Development Economics, 88(1), 103-119.

https://doi.org/10.1016/j.jdeveco.2008.01.001

Banaszewska, M., \& Bischoff, I. (2017). The Political Economy of EU-funds: Evidence from Poland. Jahrbücher Für Nationalökonomie Und Statistik, 237(3), 191-224. https://doi.org/10.1515/jbnst-2017-1105

Bracco, E., Lockwood, B., Porcelli, F., \& Redoano, M. (2015). Intergovernmental grants as signals and the alignment effect: Theory and evidence. Journal of Public Economics, 123, 78-91. https://doi.org/10.1016/j.jpubeco.2014.11.007

Brollo, F., \& Nannicini, T. (2012). Tying Your Enemy's Hands in Close Races: The Politics of Federal Transfers in Brazil. American Political Science Review, 106(4), 742-761. https://doi.org/10.1017/S0003055412000433

Calonico, S., Cattaneo, M. D., \& Farrell, M. H. (2020). Optimal bandwidth choice for robust bias-corrected inference in regression discontinuity designs. The Econometrics Journal, 23(2), 192-210. https://doi.org/10.1093/ectj/utz022 
Cattaneo, M. D., Titiunik, R., \& Vazquez-Bare, G. (2019). Power calculations for regression-discontinuity designs: The Stata Journal, 19(1), 210-245. https://doi.org/10.1177/1536867X19830919

Cox, G. W. (2010). Swing voters, core voters, and distributive politics. In A. S. Kirshner, E. J. Wood, I. Shapiro, \& S. C. Stokes (Eds.), Political Representation (pp. 342-357). Cambridge University Press. https://doi.org/10.1017/CBO9780511813146.015

Cox, G. W., \& McCubbins, M. D. (1986). Electoral Politics as a Redistributive Game. The Journal of Politics, 48(2), 370-389. https://doi.org/10.2307/2131098

Curto-Grau, M., Solé-Ollé, A., \& Sorribas-Navarro, P. (2018). Does Electoral Competition Curb Party Favoritism? American Economic Journal: Applied Economics, 10(4), 378-407. https://doi.org/10.1257/app.20160618

Deering, C. J., \& Maltzman, F. (1999). The Politics of Executive Orders: Legislative Constraints on Presidential Power. Political Research Quarterly, 52(4), 767783. https://doi.org/10.1177/106591299905200405

Fitzgerald, J., \& Curtis, K. A. (2012). Partisan Discord in the Family and Political Engagement: A Comparative Behavioral Analysis. The Journal of Politics, 74(1), 129-141. https://doi.org/10.1017/S0022381611001150 
Gendźwiłł, A., \& Żółtak, T. (2014). Why Do Non-partisans Challenge Parties in Local Politics? The (Extreme) Case of Poland. Europe-Asia Studies, 66(7), 11221145. https://doi.org/10.1080/09668136.2014.927644

Gomila, R. (2020). Logistic or linear? Estimating causal effects of experimental treatments on binary outcomes using regression analysis. Journal of Experimental Psychology: General, Advance online publication https://doi.org/10.1037/xge0000920

Hainmueller, J., Mummolo, J., \& Xu, Y. (2019). How Much Should We Trust Estimates from Multiplicative Interaction Models? Simple Tools to Improve Empirical Practice. Political Analysis, 27(2), 163-192. https://doi.org/10.1017/pan.2018.46

Jones, P. E. (2013). The Effect of Political Competition on Democratic Accountability. Political Behavior, 35(3), 481-515. https://doi.org/10.1007/s11109-012$9203-3$

Kantorowicz, J. (2017). Electoral systems and fiscal policy outcomes: Evidence from Poland. European Journal of Political Economy, 47, 36-60. https://doi.org/10.1016/j.ejpoleco.2016.12.004

Kantorowicz, J., \& Köppl-Turyna, M. (2019). Disentangling the fiscal effects of local constitutions. Journal of Economic Behavior \& Organization, 163, 63-87. https://doi.org/10.1016/j.jebo.2019.05.013 
Kauder, B., Potrafke, N., \& Reischmann, M. (2016). Do politicians reward core supporters? Evidence from a discretionary grant program. European Journal of Political Economy, 45, 39-56. https://doi.org/10.1016/j.ejpoleco.2016.09.003

Lara E., B., \& Toro M., S. (2019). Tactical distribution in local funding: The value of an aligned mayor. European Journal of Political Economy, 56, 74-89. https://doi.org/10.1016/j.ejpoleco.2018.07.006

Larcinese, V., Rizzo, L., \& Testa, C. (2006). Allocating the U.S. Federal Budget to the States: The Impact of the President. The Journal of Politics, 68(2), 447456. https://doi.org/10.1111/j.1468-2508.2006.00419.x

Lindbeck, A., \& Weibull, J. W. (1987). Balanced-budget redistribution as the outcome of political competition. Public Choice, 52(3), 273-297. https://doi.org/10.1007/BF00116710

Migueis, M. (2013). The Effect of Political Alignment on Transfers to Portuguese Municipalities. Economics \& Politics, 25(1), 110-133. https://doi.org/10.1111/ecpo.12005

Oates, W. E. (2005). Toward A Second-Generation Theory of Fiscal Federalism. International Tax and Public Finance, 12(4), 349-373. https://doi.org/10.1007/s10797-005-1619-9

Solé-Ollé, A., \& Sorribas-Navarro, P. (2008). The effects of partisan alignment on the allocation of intergovernmental transfers. Differences-in-differences 
estimates for Spain. Journal of Public Economics, 92(12), 2302-2319.

https://doi.org/10.1016/j.jpubeco.2007.06.014

Swianiewicz, P. (2020). Wpływ politiki partyjnej na rozdział dotacji celowych na przykładzie Funduszu Dróg Samorządowych. Raport dla Pisma Samorządu Terytorialnego "Wspólnota". 